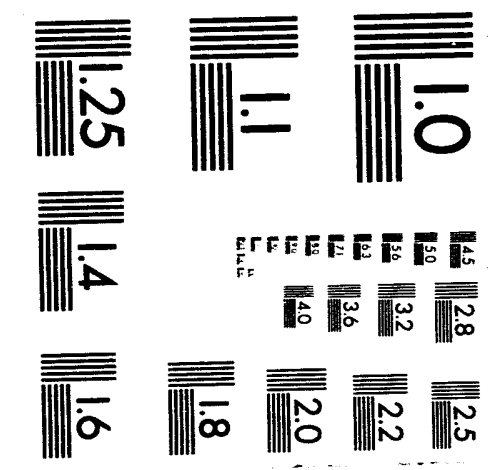






\title{
INTRODUCTION TO THE NUCLEAR CRITICALITY SAFETY EVALUATION OF FACILITY X-705, PORTSMOUTH GASEOUS DIFFUSION PLANT
}

\author{
M. K. Sheaffer \\ S. C. Keeton
}

This is an informal report intended primarily for internal or limited external distribution. The opinions and conclusions stated are those of the author and may or may not be those of the Laboratory.

Work performed under the auspices of the U.S. Department of Energy by the Lawrence Livermore National Laboratory under Contract W-7405-Eng-48.

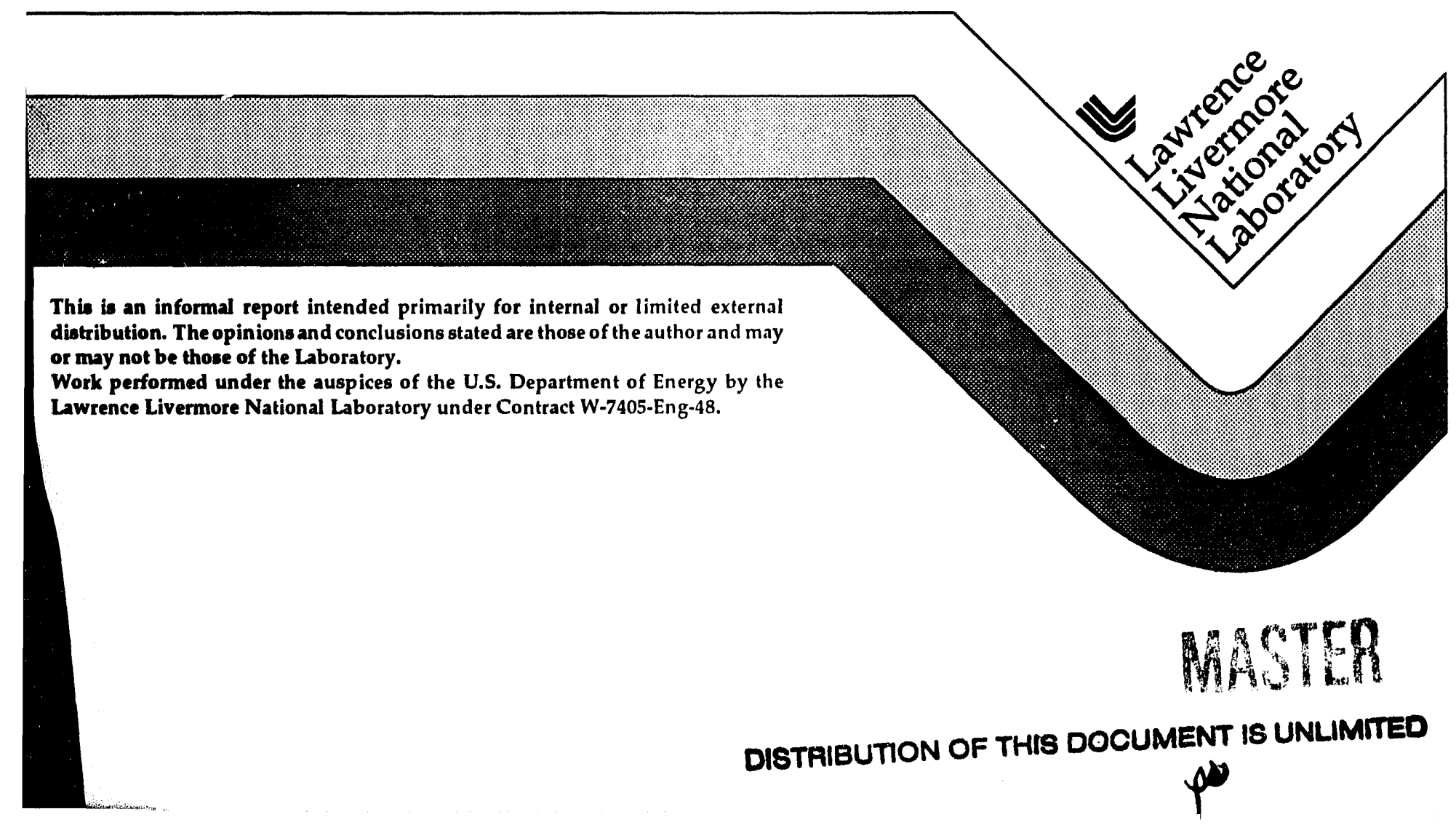




\section{DISCLAIMER}

This document was prepared as an account of work sponsored by an agency of the United States Government. Neither the United States Government nor the University of California nor any of their employees, makes any warranty, express or implied, or assumes any legal liability or responsibility for the accuracy, completeness, or usefulness of any information, apparatus, product, or process disclosed, or represents that its use would not infringe privately owned rights. Reference herein to any specific commercial products, process, or service by trade name, trademark, manufacturer, or otherwise, does not necessarily constitute or imply its endorsement, recommendation, or favoring by the United States Government or the University of California. The views and opinions of authors expressed herein do not necessarily stute or reflect those of the United States Government or the University of California, and shall not be used for advertising or product endorsement purposes.

This report has been reproduced directly from the hest available copy.

Available to DOE and DOE contractors from the Omice of Scientific and Technical Information P.O. Box 62, Ouk Ridge, TN 37831

Prices available from (615) 576-8401, FTS 626-8401

A vailable to the public from the National Technical Information Service

U.S. Department of Commerce 5285 Port Royal Rd., Springlield, VA 22161 


\section{Introduction to the nuclear criticality safety evaluation of facility X-705, Portsmouth Gaseous Diffusion Plant}

16 Aug 1993

Lawrence Livermore National Lab., CA (United States)

Reproduced and Distributed by:

U.S. DEPARTMENT OF ENERGY

Office of Scientific and Technical Information P.O. Box 62

Oak Ridge, TN 37831 


\section{ACKNOWLEDGMENTS}

We would like to thank the numerous PORTS personnel who assisted in the collection of information for this report and who took time from their busy schedules to acquaint us with the operations in X-705. This report would not have been possible without the cooperation of Rob Oxenham and Donna D'Aquila of the PORTS NCS Department. Specific recognition should also be given to the X-705 staff, who had to deal with us on many occasions for several days at a time while we attempted to learn the complex operation of their facility. Melody Channel's support of our administrative and logistical requirements was truly outstanding. D.D. Atkins, Kevin Clausing, Karen Foster, John Oppy, Rudy Spaeth, Bob Stanley, John Urik, and Greg Wells played a significant role in explaining $X-705$ operations and in providing valuable insight on the day-to-day activities of this many-facetted facility.

Finally, we wish to acknowledge the support we received from the MMES staff at Oak Ridge, particularly Tom Lemons, Curtis Jordan, and Howard Dyer. 
Page

ACRONYMS. iv

ABSTRACT. v

1.0 INTRODUCTION. 1

$2.0 \times-705$ FACILITY. 2

2.1 Description. 2

2.2 Systems 2

2.3 Subsystems and Operational Areas. 3

3.0 EXISTING NCS DOCUMENTATION. 11

3.1 Final Safety Analysis Report and Operational Safety Requirements.. 11

3.2 Development Memos and Reports....................................................... 11

3.3 Field Agreements and Facility Change Agreements........................... 12

3.4 Operating Methods................................................................................. 13

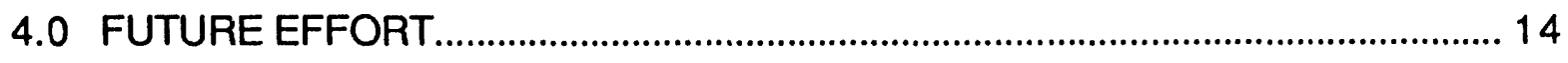

4.1 Detailed NCS Evaluations................................................................. 14

4.2 Documentation Listing........................................................................ 14

4.3 Update of Subsystems, Operational Areas, and Documentation......... 14

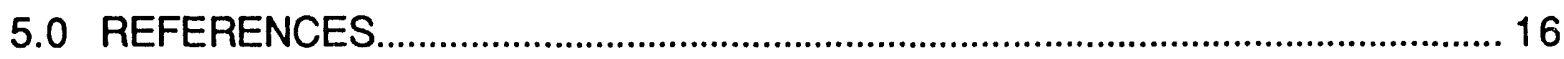

APPENDIX A - CORRELATION OF FSAR WITH SYSTEMS, SUBSYSTEMS, AND OPERATIONAL AREAS

APPENDIX B - CORRELATION OF OSRS WITH SYSTEMS, SUBSYSTEMS, AND OPERATIONAL AREAS

APPENDIX C - CORRELATION OF DMS, T-REPORTS, AND FCAS WITH SYSTEMS, SUBSYSTEMS, AND OPERATIONAL AREAS 
TABLE OF CONTENTS (CON'T)

\begin{abstract}
APPENDIX D - NUMERICAL LISTING OF FCAs FOR X-705 (PUBLISHED SINCE 1985)
\end{abstract}

APPENDIX E - CORRELATION OF OMS AND IPS WITH SYSTEMS, SUBSYSTEMS, AND OPERATIONAL AREAS 


\section{ACRONYMS}

$\begin{array}{lll}\text { ANSI } & - & \text { American National Standards Institute } \\ \text { ANS } & - & \text { American Nuclear Society } \\ \text { ANT } & - & \text { Applied Nuclear Technology } \\ \text { DOE } & - & \text { Department of Energy } \\ \text { DYMCAS } & - & \text { Dynamic Material Control Accounting System } \\ \text { ESR } & - & \text { Engineering Services Request } \\ \text { FA } & - & \text { Field Agreement } \\ \text { FCA } & - & \text { Facility Change Agreement } \\ \text { FSAR } & - & \text { Final Safety Analysis Report } \\ \text { GAT } & - & \text { Goodyear Atomic Corporation } \\ \text { GDP } & - & \text { Gaseous Diffusion Plant } \\ \text { HEU } & - & \text { Highly enriched uranium } \\ \text { IP } & - & \text { In-Hand Procedure (formerly OM) } \\ \text { LLNL } & - & \text { Lawrence Livermore National Laboratory } \\ \text { MSDS } & - & \text { Material Safety Data Sheet } \\ \text { MMES } & - & \text { Martin Marietta Energy Systems, Inc. } \\ \text { NCS } & - & \text { Nuclear Criticality Safety } \\ \text { NCSA } & - & \text { Nuclear Criticality Safety Approval } \\ \text { PEH } & - & \text { Planned Expeditious Handling } \\ \text { PGDP } & - & \text { Paclucah Gaseous Diffusion Plant, Paducah, Kentucky } \\ \text { PORTS } & - & \text { Portsmouth Gaseous Diffusion Plant, Piketon, Ohio } \\ \text { OA } & - & \text { Operational Area } \\ \text { OGRU } & - & \text { Oil and Grease Removal Unit } \\ \text { OM } & - & \text { Operating Method } \\ \text { OSR } & - & \text { Operational Safety Requirement } \\ \text { RP } & - & \text { Reference Procedure } \\ \text { S } & - & \text { System } \\ \text { SS } & - & \text { Subsystem } \\ \text { UES } & - & \text { Uranium Enrichment Support } \\ & & \end{array}$




\section{ABSTRACT}

This report is the first in a series of documents that will evaluate nuclear criticality safety in the Decontamination and Recovery Facility, X-705, Portsmouth Gaseous Diffusion Plant. It provides an overview of the facility, categorizes its functions for future analysis, reviews existing NCS documentation, and explains the follow-on effort planned for X-705. A detailed breakdown of systems, subsystems, and operational areas is presented and cross-referenced to existing NCS documentation. 


\subsection{INTRODUCTION}

As part of its overall Uranium Enrichment Support (UES) Project, the Department of Energy (DOE) has tasked Lawrence Livermore National Laboratory to provide nuclear criticality safety (NCS) support to the gaseous diffusion plants (GDP), operated by Martin Marietta Energy Systems (MMES), near Portsmouth, Ohio, and Paducah, Kentucky. One requirement of this GDP NCS Task, as defined by MMES, is a criticality evaluation of the Decontamination and Uranium Recovery Facility, X-705, at the Portsmouth Gaseous Diffusion Plant (PORTS).

This report is the first in a series of documents that will evaluate nuclear criticality safety in X-705. Its primary purposes are to: (1) provide an overview of the facility, (2) categorize the facility operations and equipment for future analysis, (3) review the existing NCS documentation relative to X-705, and (4) explain the follow-on effort.

Section 2.0 of this report provides a general description of X-705 and discusses a functional breakdown of its systems, subsystems, and operational areas. Section 3.0 summarizes the various types of MMES NCS documentation, with specific details on those relative to X-705, and correlates these numerous NCS documents with the systems, subsystems, and operational areas. An overview of the future effort planned for the X-705 assessment is then presented in Section 4.0.

The information on systems, subsystems, and operational areas presented in this report was current as of September 1992. 


\section{$2.0 \quad X-705$ FACILITY}

\subsection{Description}

The $X-705$ building is a permanent structure, approximately 520 feet by 160 feet, with a concrete slab floor, concrete and transite walls, and steel support columns. Steel trusses support a metal roof deck, covered by insulation and roofing. The building is sited in the northern part of the plant and centrally located with respect to the $X-326, X-330$, and $X-333$ process buildings. $X-705$ is managed by the Chemical Operations Department, Uranium Production Subdivision.

The primary purpose of the $X-705$ facility is to decontaminate process equipment from the uranium enrichment cascade prior to maintenance, modification, or other disposition. Other uranium-contaminated items, such as heeled uranium hexafluoride $\left(\mathrm{UF}_{6}\right)$ cylinders and chemical trap material, are also processed in X-705.

The procedures used to decontaminate equipment produce a significant quantity of uranium-bearing solutions. Solutions with high uranium concentration are processed in X-705 to recover the uranium (in oxide form) for potential future use and to remove other unacceptable materials before the effluents are released to the environment. Solutions with low uranium content are also treated to remove uranium, which is collected in waste storage drums.

Until 1978 the recovered uranium $\left(\mathrm{U}_{3} \mathrm{O}_{8}\right)$ was further converted to $\mathrm{UF}_{6}$ in X-705 so that it could be reintroduced into the cascade. Environmental concerns resulted in the discontinuance of that process, and the oxide is now simply stored in other plant facilities. No program appears to exist to consider restart of the oxide conversion process.

Finally, in order to perform the above functions of decontamination, uranium recovery, and water treatment, a number of support services are required. These include, for example, utility services, maintenance capability, laboratory analyses, and administrative support. In general, the major support services required in X-705 are located within the building itself.

\subsection{Systems}

As discussed in Section 2.1, X-705 is a large facility housing numerous activities and support services. In order to perform an NCS evaluation of the entire facility, it is first necessary to divide X-705 into logical categories of related activities that can be analyzed individually. These individual activities nan then be consolidated, with particular attention to their interfaces, in order to achieve an overall NCS evaluation. 
For this study, X-705 has been divided into five top-level systems based on general functional area:
(1) Decontamination
(2) Uranium Recovery
(3) Oxide Conversion
(4) Waste Water Treatment
(5) Support Services

This breakdown is shown schematically in Fig. 2.1. The reader should note the direct correspondence between these functions and the description of X-705 discussed in Section 2.1.

Other criteria, besides functional area, could have been chosen as the basis for breakdown. These include, but certainly are not limited to, location within the building, input stream, output stream, etc. Because the selection of functional area obviously impacts the remainder of the study, it is probably worthwhile to discuss briefly the rationale for its selection. First, it provides a very logical relationship between the various activities and enables a methodical description of the work flow within the facility. It correlates very well with $X-705$ supervisory responsibilities and reasonably well (but not exactly) with the physical layout of the building. Finally, as will be seen in Section 3.0, it corresponds in general to previous breakdowns used for preparing documentation relative to $\mathrm{X}-705$.

Each of these top-level systems will next be described in more detail.

\subsection{Subsystems and Operational Areas}

Each of the five top-level systems described above can be further divided into activities or groups of activities. For the purposes of this study the level of breakdown below the system will often be referred to as subsystems (SS). In many cases it is advantageous to divide these subsystems further into operational areas (OA). This section provides a more-detailed description of X-705 and the relationship among the systems, subsystems, and operational areas. Table 2.1 summarizes this breakdown and provides the detailed numbering system referenced in later sections. Fig. 2.2 is a schematic layout of X-705 to assist the reader in following the discussion below. (This figure is not exactly to scale and displays only sufficient detail to enable the reader to understand the relative layout of the building.)

\subsubsection{Decontamination System [S1.0]}

Equipment usually enters X-705 through the large doors on the east and west side of the north end of the building. (Highly contaminated equipment or equiprnent containing high-assay material is generally first processed in the South Annex [OA1.1.3].) 


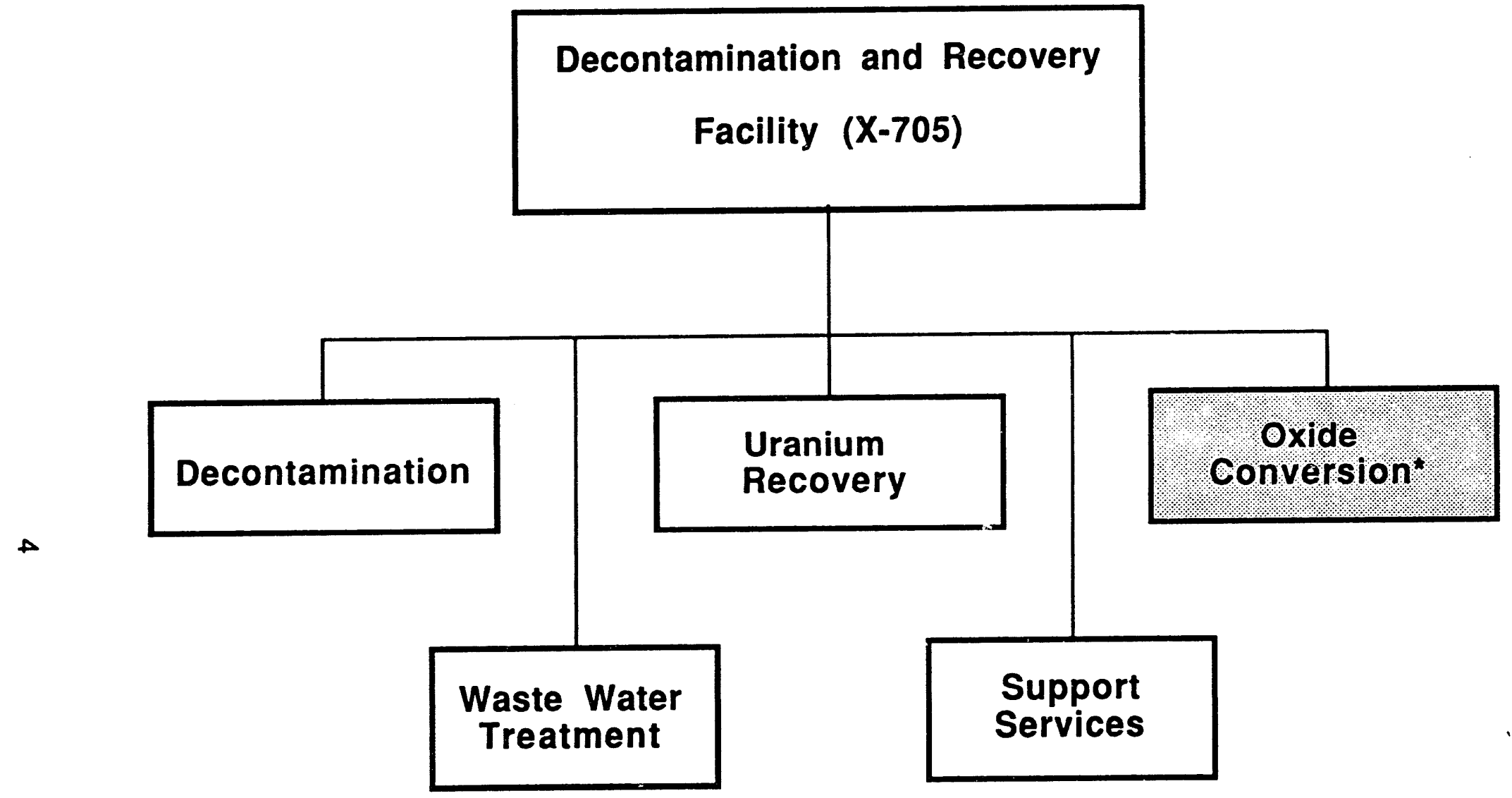

*No longer operational

Figure 2.1 Major systems of the X-705 facility 


\section{SYSTEM/ SUBSYSTEM/ OPERATIONAL AREA}

1.0 Decontamination (High Bay)

1.1 Large Parts Disassembly \& Decontamination (C Area)

1.1.1 Compressor Disassembly

1.1.2 Converter Disassembly

1.1.3 South Annex Operations

1.1.4 Spray Booth Operations

1.1.5 Truck Alley Cleaning

1.1.6 General Storage and Handling

1.2 Small Parts Cleaning (A Area)

1.2.1 30-in. and 48-in. Cylinder Cleaning

1.2.2 8-in. and 12-in. Cylinder Cleaning

1.2.3 5-in. Cylinder Cleaning

1.2.4 Cylinder Drying, Conditioning, and Testing

1.2.5 Sodium Fluoride Pellet Conditioning

1.2.6 Seal and Small Parts Dismantling

1.2.7 Small Parts Handtable Operations

1.2.8 Small Parts Pit Operations

1.2.9 Sand and Glass Blasting

1.2.10 General Storage and Handling

1.2.11 Trichloroethylene Degreasing

1.3 Vacuum Cleaners

2.0 Uranium Recovery (B Area)

2.1 Mixed Acids Precipitation (A Area)

2.2 Trap Material Leaching

2.2.1 Spray Tank Operations (A Area)

2.2.2 Flocculating Columns/Vacuum Filter Table

2.2.3 Unmeasured Storage

2.3 Fluorides-Complexing Handtable (A Area)

2.4 Recovery/Blending Handtable Operations

2.5 Measured Solution Storage (B-36, B-38, B-1, and Tunnel)

2.6 Volume Reduction/Chemical Processing

2.7 Calciners

2.8 Nitrogen Oxide Scrubbers

2.9 Raffinate Storage

2.10 Heavy Metals Precipitation

2.11 Technetium lon Exchange

2.12 General Storage and Handling

2.13 Continuous Dissolver

2.14 Mixed Acids Precipitation (B Area)

2.15 Neutralization System

2.16 Incinerator 


\section{Table 2.1 Breakdown of X-705 (continued)}

\section{SYSTEM/ SUBSYSTEM/ OPERATIONAL AREA}

3.0 Oxide Conversion (E/F/H Area)

3.1 UNH Calciner (F Area)

3.2 General Storage and Handling

4.0 Waste Water Treatment Systems

4.1 Condensate Recovery

4.2 Rinse Booth Recirculating Storages

4.3 Cylinder Solution Microfiltration

4.4 Oil and Grease Removal Unit

4.5 Solution Collection and Storage

4.6 Microfiltration/Pressure Filtration

4.7 Effluent Pumping Station

4.8 Tunnel Sumps

4.9 General Storage and Handling

5.0 Support Areas
5.1 Maintenance Shop (D Area)
5.2 Process Laboratory (G Area)
5.3 Laundry
5.4 Office Area
5.5 Acid/Solvent Receiving, Storage, Transfer (H Area)
5.6 Ventilation, Exhaust, and Utilities
5.7 Drains
5.8 General Storage and Handling
5.9 Miscellaneous

Notes:

(1) Systems, subsystems, or operational areas that are no longer operational are indicated with italics.

(2) A category of "General Storage and Handling" has been added to various systems and subsystems to include activities that are difficult to assign specifically to a given area. 


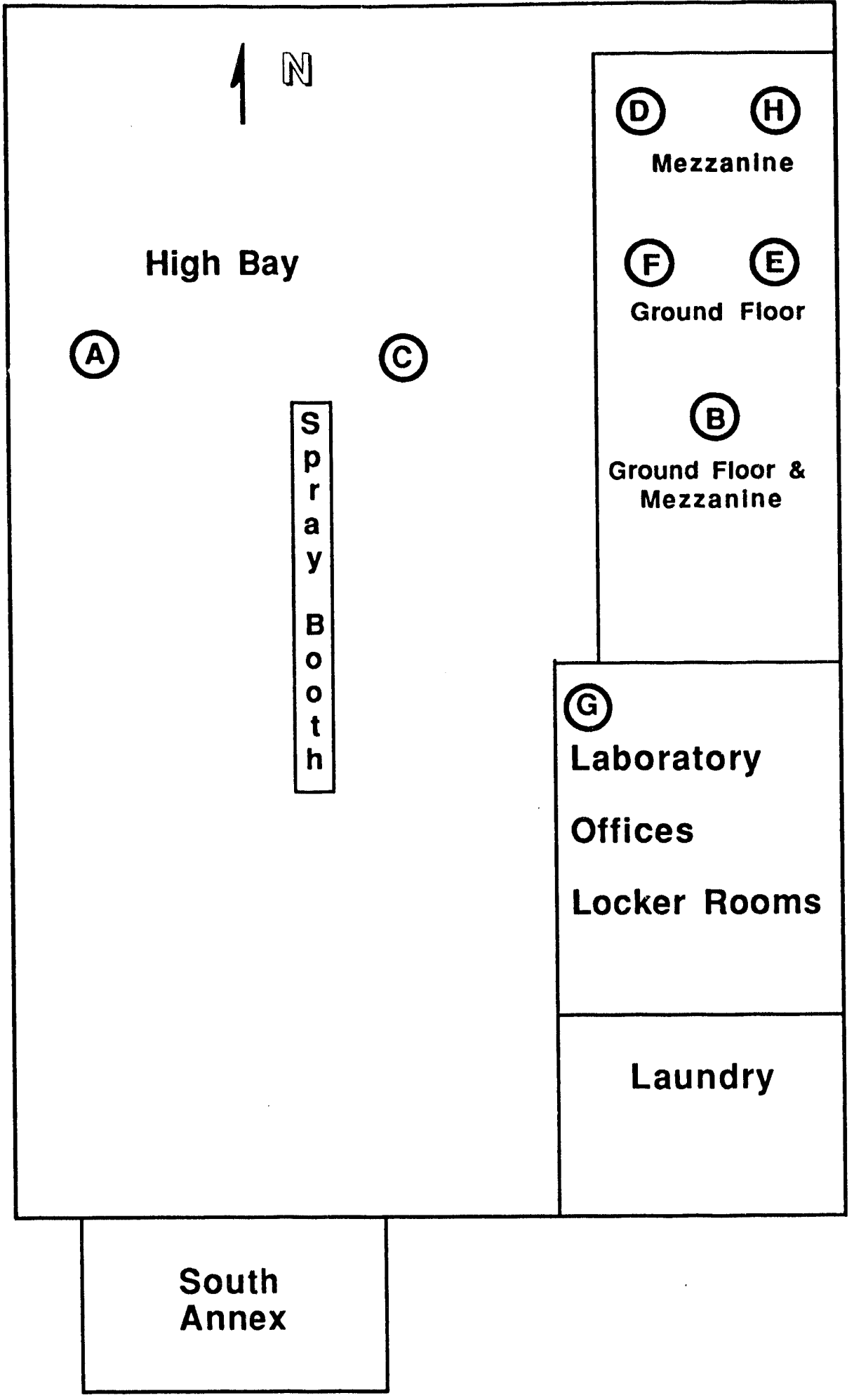

Figure 2.2 Schematic layout of X-705 
Large equipment [SS1.1], such as compressors [OA1.1.1] and converters [OA1.1.2], are disassembled in the northeast side of the high bay, which is often referred to as " $\mathrm{C}$ " area. Converters have not been processed recently in X-705, and, in fact, some of the equipment unique to this operation is currently being removed from the building. Large parts are cleaned with acid sprays and a water rinse in the spray booth [OA1.1.4], often called the tunnel area. The northern-most center of the high bay, called the truck alley [OA1.1.5], is used for weakly contaminated large equipment that can not be easily cleaned in the spray booth.

Small equipment [SS1.2] is treated in the northwest side of the high bay, known as "A" area. "Empty" $U F_{6}$ cylinders are cleaned [OA1.2.1-1.2.3] to remove the nonvolatile heels that remain. Because the assay of $U F_{6}$ that can be stored in a cylinder depends on its size, the cleaning procedures vary with the size of the cylinder. Cleaned cylinders are then dried, conditioned, and tested [OA1.2.4] prior to release. Sodium fluoride pellets, purchased as $\mathrm{HNaF}_{2}$, are first dried [OA1.2.5] in $\mathrm{X}-705$ to remove hydrogen fluoride gas before being used as trapping material in various plant processes. Small parts that require special handling (e.g., for airborne contamination) are treated in the seal and small parts dismantling room [OA1.2.6]. Other small parts are cleaned in the small parts handtables [OA1.2.7] and, after visible contamination is removed, steam cleaned in the small parts pit [OA1.2.8]. Glass blasting [OA1.2.9] is sometimes required to remove contamination remaining after normal cleaning processes. (The sand blasting aspect of [OA1.2.9] and trichloroethylene decreasing [OA1.2.11] are no longer performed.)

The last subsystem under decontamination is vacuum cleaners [SS1.3]. This category has been separately identified because several types of vacuum cleaners are used at various places in the decontamination process.

\subsubsection{Uranium Recovery System [S2.0]}

Highly concentrated solutions are processed in $X-705$ to recover the uranium (in oxide form) for potential future use and to remove other unacceptable materials before the effluents are relurned to the environment. Most of this uranium recovery operation takes place in "B" area, the ground floor/mezzanine shown in Fig. 2.2, although initial treatment may begin in the small parts ("A") area.

Many discarded laboratory solutions contain acids (other than nitric), which for various reasons should not be processed through normal recovery hardware. Although mixed acids precipitation was previously performed in "B" area [SS2.14], these procedures have been discontinued. Current plans envision the use of the minimicrofiltration system (once used for cylinder wash solutions) in "A" area [SS2.1]; however, the exact procedures have yet to be refined and implemented.

Another recovery operation beginning in " $A$ " area is trap material leaching [SS2.2]. Alumina and sodium fluoride trap materials are cleaned in the spray tanks [OA2.2.1] (as opposed to spray booths discussed in Section 2.3.1). Uranium solutions 
are then pumped to flocculating columns and the vacuum filter table in " $\mathrm{B}$ " area [OA2.2.2], where solids are filtered out and the solutions stored in columns for later processing. These unmeasured storage columns [OA2.2.3] were previously part of a continuous dissolver [SS2.13], which is no longer operational.

Various uranium-bearing solids and solutions that may contain fluoride ions are treated in the fluorides-complexing handtable [SS2.3] in " $\mathrm{A}$ " area to reduce corrosion in the stainless steel plumbing throughout the recovery process. These solutions and other uranyl nitrate solutions that have been collected in polybottles are taken to the recovery/blending handtable [SS2.4] in "B" area.

Solutions from both the recovery/blending handtable and the unmeasured storage (leaching operation and contaminated acids from spray booth) are pumped to the B-36/B-38 storage columns [SS2.5], where they can be properly mixed and their volume, concentration, and assay accurately determined before transfer to the B-1 measured storage columns or measured tunnel storage.

Continued processing of the uranium solutions can be performed in any of three ( $A, B$, or $C$ ) essentially identical loops [SS2.6], in which the solution is separated into a product (uranium-bearing) and waste (uranium-depleted) stream. The concentrated product stream proceeds through a calciner [SS2.7]. Here the uranyl nitrate is converted to oxide $\left(\mathrm{U}_{3} \mathrm{O}_{8}\right)$, which is collected in 5-in. cans for storage. Gases produced from the calcining process are scrubbed to remove nitrogen oxides [SS2.8].

Liquids depleted in uranium are collected at various stages during the recovery process. The waste streams (called raffinates [SS2.9]) from A, B, or C loop are further treated to remove heavy metals [SS2.10] and the fission product technetium [SS2.11] before discharge from $X-705$ to the biodenitrification facilities in X-700. Other depleted waste solutions are processed through the waste water treatment system [S4.0]. The neutralization system [SS2.15] and incinerator [SS2.16] are no longer operational.

\subsubsection{Oxide Conversion System [S3.0]}

The oxide conversion processes in "E/F/H" areas are generally not operational. A glove box in " $F$ " area is occasionally used, and the areas are available for general storage [SS3.2]. The calciner in " $F$ " area that was previously used for uranium nitrate compounds [SS3.1] is no longer functional, although still in place.

\subsubsection{Waste Water Treatment System [S4.0]}

The decontamination and recovery operations produce various slightly contaminated solutions for which the uranium is not economically recoverable, but, nevertheless, must be removed before the solution can be discharged to the environment. During the volume reduction process of uranium recovery, low uraniumconcentration condensate [SS4.1] is produced by the vapor separator/condenser segment of both the pre- and post-evaporators. Rinse-water solutions from spray- 
booth-rinse recirculating storage [SS4.2] and cylinder rinsing [SS4.3] are also slightly contaminated. Uranium must also be removed from the effluent of the Oil and Grease Removal Unit (OGRU) [SS4.4], located in truck alley.

The slightly contaminated solutions are collected in a 7000-gal. overhead storage unit [SS4.5]. This unit consists of 14 stainless steel pipes (5-in diameter), which traverse north-south along most of the length of the high bay. Uranium removal is accomplished by the microfiltration/pressure filtration subsystem [SS4.6]. The sludge produced from the concentrate of this process is batched into 55-gal drums; the permeate is transferred to the effluent pumping station [SS4.7], before discharge from $\mathrm{X}-705$.

The final and distinct subsystem of waste water treatment is the tunnel sumps [SS4.8]. These sumps are located in the north and south ends of the basement of the spray booth tunnel. Ground water that accumulates in these sumps is slightly contaminated with non-uranium compounds and cannot be discharged directly to the environment. This water is pumped to truck-mounted water tanks for transport to additional processing facilities.

\subsubsection{Support Services System [S5.0]}

This system consists of all the functions needed to provide general support for the operations in X-705. The maintenance shop [SS5.1] in "D" area contains all tools necessary for disassembly and selected rebuilding of process equipment. The primary purpose of the "G"-area laboratory [SS5.2] is to determine uranium concentrations of solutions. Uranium assays (percent enrichment) are performed by personnel from Applied Nuclear Technology (ANT). The laundry [SS5.3] and administrative offices [SS5.4] in X-705 are also included in this system. In addition, several of the decontamination and recovery operations require acids and solvents that are stored in "H"-area tanks [SS5.5] for distribution throughout the building as needed.

A number of other subsystems have been included under support services primarily because they do not fit well in other systems but need to be examined. These include ventilation, exhaust, and utilities [SS5.6] and drains [SS5.7]. Finally, a general miscellaneous category [SS5.9] was added to collect any remaining activities that may be identified for examination. 


\subsection{EXISTING NCS DOCUMENTATION}

During the approximately 40 years of PORTS operation an extensive amount of NCS documentation has been published. This section présents a general overview of the various types of NCS documents and provides more detailed information on those specific to X-705.

\subsection{Final Safety Analysis Report and Operational Safety Requirements}

The top-level safety-related PORTS document is the Final Safety Analysis Report (FSAR)i, a three-volume report originally published in 1985. Volume 1 provides an introduction to the plant, general site information, and a summary safety analysis. Volume 2 describes detailed operations of the entire plant, and Volume 3 discusses accident scenarios and analyses.

The majority of the information in the FSAR relative to X-705 is contained in Section 4.3 (Volume 2) and Section 5.3 (Volume 3). Although the FSAR has been updated several times since first published, a number of X-705 operations appear to be no longer accurately documented, and a significant revision of the FSAR is presently in progress. Appendix $A$ is a detailed listing of the systems, subsystems, and operational areas in X-705 and the respective sections in which they are discussed in the FSAR. Those areas presented in the FSAR but no longer operational are indicated in italics.

Another top-level document mandated by DOE is the Operational Safety Requirements (OSRs), reported in GAT/GDP-1074. (DOE Order 5480.22 now prescribes Technical Safety Requirements, rather than OSRs.) Part $H$ (Rev. 3) of GAT/GDP-1074 contains safety limits, limiting conditions for operations, surveillance requirements, design features, and administrative controls for $X-705$. This information is cross-referenced to the $X-705$ systems, subsystems, and operational areas in Appendix B.

The OSRs for X-705 are similar, but not identical, to information contained in Section 4.3.2.2 of the FSAR. The rationale for the differences is not clear.

\subsection{Development Memos and Reports}

Development Memos (DMs) were initiated in 1954 by the Development Subdivision in order to transmit functional information directly to individuals concerned. Development Reports were similar in purpose to DMs but were reserved for the results of a study or investigation and were addressed only to the manager of Development Engineering. Both of these types of documents were initially rather informal in nature ${ }^{2}$. 
Over the years, however, these procedures have evolved into a much more formal reporting system, which now consists of Development Memos and T-Reports. Sometimes the DMs for a particular facility or building have been consolidated into a single DM, whose length can exceed 100 pages. Whether or not a topic is covered in a DM or T-Report has varied in recent years. Although these documents contain very authoritative language (e.g., "ACTIONS TO BE TAKEN"), they apparently serve only as a guide for the operating department 3 .

During the early 1960 s the various DMs pertaining to X-705 were consolidated into DM-868. The most current revision, Rev. 4, was published in 1984 and incorporated all previous DMs, T-Reports., and FCAs (see next section) pertaining to $\mathrm{X}-705$. (One addendum to DM-868 was published in 1985, but this was later superseded by FCA-382, as discussed in the next section.) Over the past seven years, however, a number of additional DMs and a few T-Reports concerning the operations in X-705 have been separately published. Appendix $C$ cross-references pages of DM-868, other DMs, and T-Reports to the appropriate systems, subsystems, and operational areas of $\mathrm{X}-705$.

DM-868 is obviously not current. Major hardware/equipment changes have occurred since the document was last revised, and many of the activities discussed are either no longer performed or are performed in a manner different from that described. Overall, the document is rather confusing. The breakout by functional area is not obvious without reference to the Table of Contents, which unfortunately does not include page numbers. The format of the discussions is not consistent, probably the result of their being written over a several-decade time frame. DM-868 also contains numerous errors, some that appear substantive as well as typographical. References to figures by number are often inaccurate.

No plans exist to revise DM-868. Instead, a Nuclear Criticality Safety Approval (NCSA) will be prepared on each operational area in X-705. The follow-on effort by LLNL, discussed in Section 4.0, should be the basis for many of these NCSAs.

\subsection{Field Agreements and Facility Change Agreements}

Field Agreements (FAs) and Facility Change Agreements (FCAs) are formal interim agreements, signed by all parties involved, concerning safe operating practices ${ }^{3}$. FAs are more temporary, with lifetimes that have typically varied from a few weeks to a few months. FCAs define the NCS aspects of more permanent operations. Some FCAs (e.g., FCA-272 and FCA-273) appear to have been initially written as FAs.

With their formality and signature requirements, FCAs appear to be very authoritative in nature. They explicitly state actions that will or will not be performed. In the past, however, FCAs have often been canceled after being incorporated into the next revision of the applicable DM. Since DMs now appear to be guides, it could be 
argued that the actions required by these FCAs are no longer mandatory. The use of NCSAs, discussed above, should clarify this situation.

Since the last revision of DM-868, at least 67 FCAs have been implemented for $X-705$, and 53 of these are still active. (A total of 50 FCAs specific to X-705 were identified; two other FCAs pertaining to vacuum cleaners and one on $U F_{6}$ cylinders are included in the 53.) Determining which FCAs are applicable to X-705 and which have not been canceled or superseded is not a straightforward task. Some FCAs that pertain to other facilities also contain information relevant to X-705 operations. For example, FCA-523, which permits the on-site use of $48 X$ (10-ton) cylinders for $5 \%$ enrichment, is indexed under $X-326$ and $X-333$. This practice, however, definitely impacts Large Cylinder Cleaning [OA1.1.1] in X-705. Appendix D provides a listing of all FCAs identified for X-705 since 1985 (previous FCAs were superseded by Rev. 4, DM-868) and the authority for cancellation, if applicable. Because of the possibility that canceled or superseded FCAs may have been removed from the data base, this listing may not be complete. A cross-reference of FCAs currently active for X-705 is shown along with the DMs in Appendix C.

At the time this document was initially prepared (summer 1992), two active Field Agreements for X-705 were identified. FA 92-16 addressed the expansion joints in the pre- and post-evaporators of the recovery area [SS2.6] and superseded FCA-564. FA 92-17 provided temporary authorization to use the cylinder microfiltration subsystem [SS4.3] for mixed-acid processing, as mentioned in Section 2.3.4 of this report.

\subsection{Operating Methods}

Each of the specific operations performed in a PORTS facility is generally covered in an Operating Method (OM). Recently, the nomenclature for these documents has been changed to In-Hand Procedures (IPS), Reference Procedures (RPs), and other types of Procedures, depending on their intended use. As Operating Methods are revised, the designation of OM will gradually disappear.

OMs and IPs are very detailed, usually step-by-step, instructions designed to instruct operations personnel on the actual procedures for a given activity. New IPS and final revisions to existing OMs and IPs are approved by the Operations Committee, although interim (red-line) changes can be instituted unilaterally by line management. For ease in identification, interim changes are now printed on yellow paper, final revisions on blue paper.

A list of the OMs and IPS for X-705, referenced to the applicable system, subsystem, or operational area, is shown in Appendix $E$. Because a significant effort is now under way to update OMs and modify their numbering procedure, only the basic OM number is indicated in each case. Future analyses of the individual areas will provide the actual revision, changes, and addenda in effect at that time. 


\subsection{FUTURE EFFORT}

As discussed in earlier sections, the NCS documentation for X-705 is extensive. Over the years an impressive effort has been crevoted to analysis of criticality safety. The fact that $X-705$ has operated safely for almost 40 years is a tribute to both the operational personnel anu NCS staff. As operational procedures change and new equipment is introduced, however, it eventually becomes prudent to reevaluate the overall facility from a bottoms-up basis. Such is the task for this future effort.

\subsection{Detailed NCS Evaluations}

A detailed NCS evaluation will be performed for all subsystems and operational areas identified (in priority) by MMES. A report on each of these areas will include a more detailed description of the operations performed, the equipment in the area, and input/output fissile streams. Specific attention will be devoted to interfaces among the subsystems and operational areas.

The evaluation will be performed in general accordance with the ANSI series 8 requirements, and in particular with ANSI $8.1^{4}$ (as modified by current DOE orders). This analysis will be fully documented and will address control parameters, safety systems, and administrative controls. Both normal and off-normal (including accident) events will be examined, and a specific assessment of the double contingency principle will be provided.

\subsection{Documentation Listing}

Each evaluation will be accompanied by a complete listing of applicable documentation. This listing will include all current NCS documentation for the specific subsystem or operational area under review and any other safety-related documents deemed appropriate by LLNL or MMES.

\subsection{Update of Subsystems, Operational Areas, and Documentation}

As discussed earlier, one of the primary purposes of this report is to serve as a starting point and road map for future evaluations. The breakdown of X-705 into subsystems and operational areas (and cross-referencing with NCS documentation) presented in previous sections of this report was performed after a summary review of existing documentation and initial discussions with MMES NCS and operational personnel. Because of the large number of significant changes that have occurred in $X-705$ since some of the documentation was published, it was often difficult to determine if specific documentation is still applicable and, if so, to which (muchchanged) operational area. Obviously, no totally accurate breakdown can be completed until the individual subsystems and operational areas are evaluated and all existing documentation examined in detail. During these detailed evaluations it is envisioned that the X-705 breakdown (especially interfaces) will be refined and 
additional documentation identified. It is therefore anticipated that the information presented in this initial report will also need to be modified and the document revised in some manner before the overall task is completed. 


\subsection{REFERENCES}

1 GAT/GDP-1073, Portsmouth Gaseous Diffusion Plant Final Safety Analysis Report, Volume 1-3, April 1985.

2 Development Memo No. 2, Format for the Preparation of Development Memos and Reports, Goodyear Atomic Corporation, April 7, 1954.

3 Standard Practice Procedure H-30, Nuclear Criticality Safety, Martin Marietta Energy Systems, Inc., April 16, 1991.

4 ANSI/ANS 8.1, American National Standard for Nuclear Criticality Safety in Operations with Fissionable Materials Outside Reactors, American Nuclear Society, October 7, 1983. 


\section{APPENDIX A}

\section{CORRELATION OF FSAR}

\section{WITH}

\section{SYSTEMS, SUBSYSTEMS, AND OPERATIONAL AREAS}

Note: In addition to the specific sections listed in this appendix, Section 4.3.2.2 of the FSAR contains information that is similar, but not identical, to that contained in the OSRs (see Appendix B). 







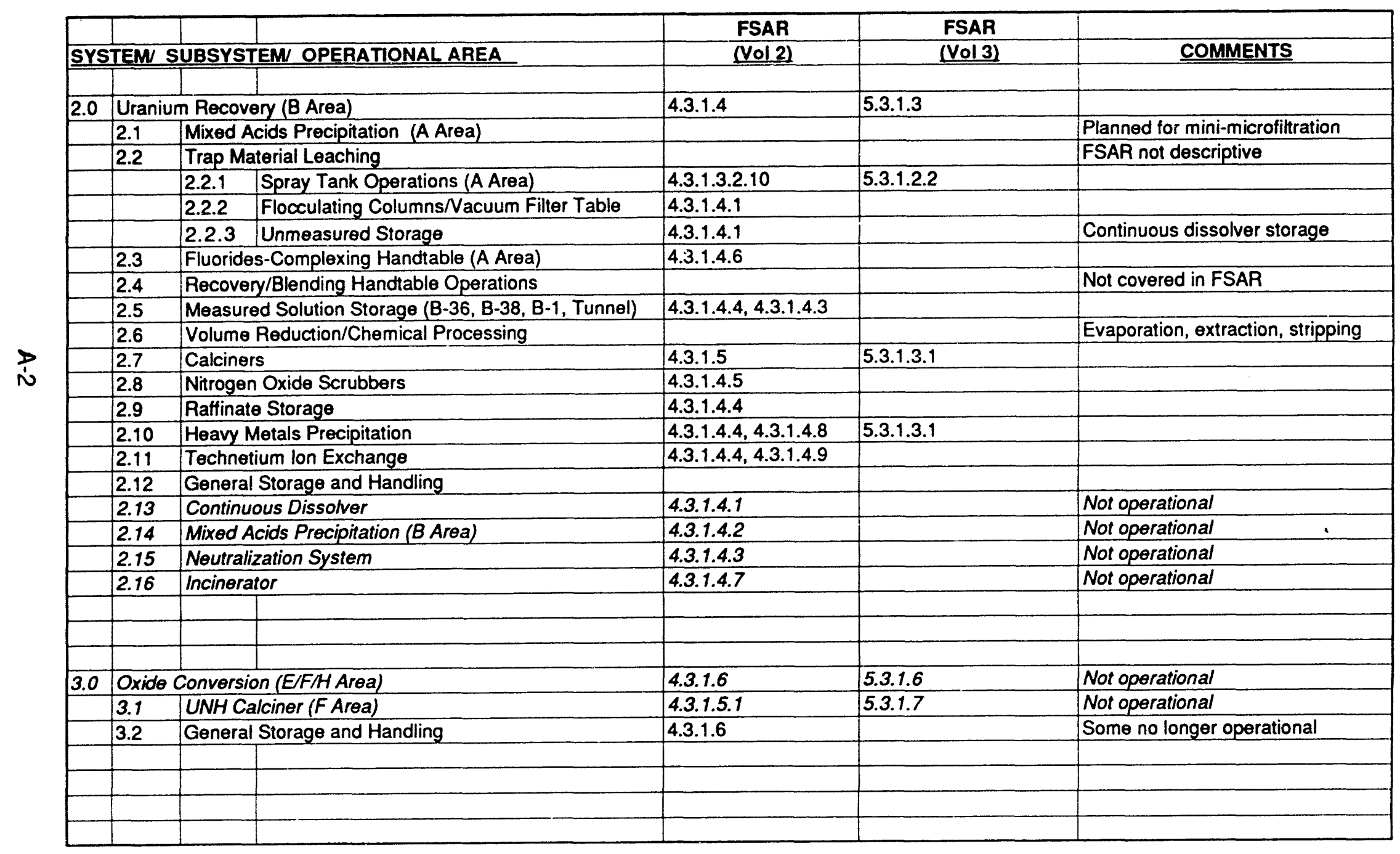




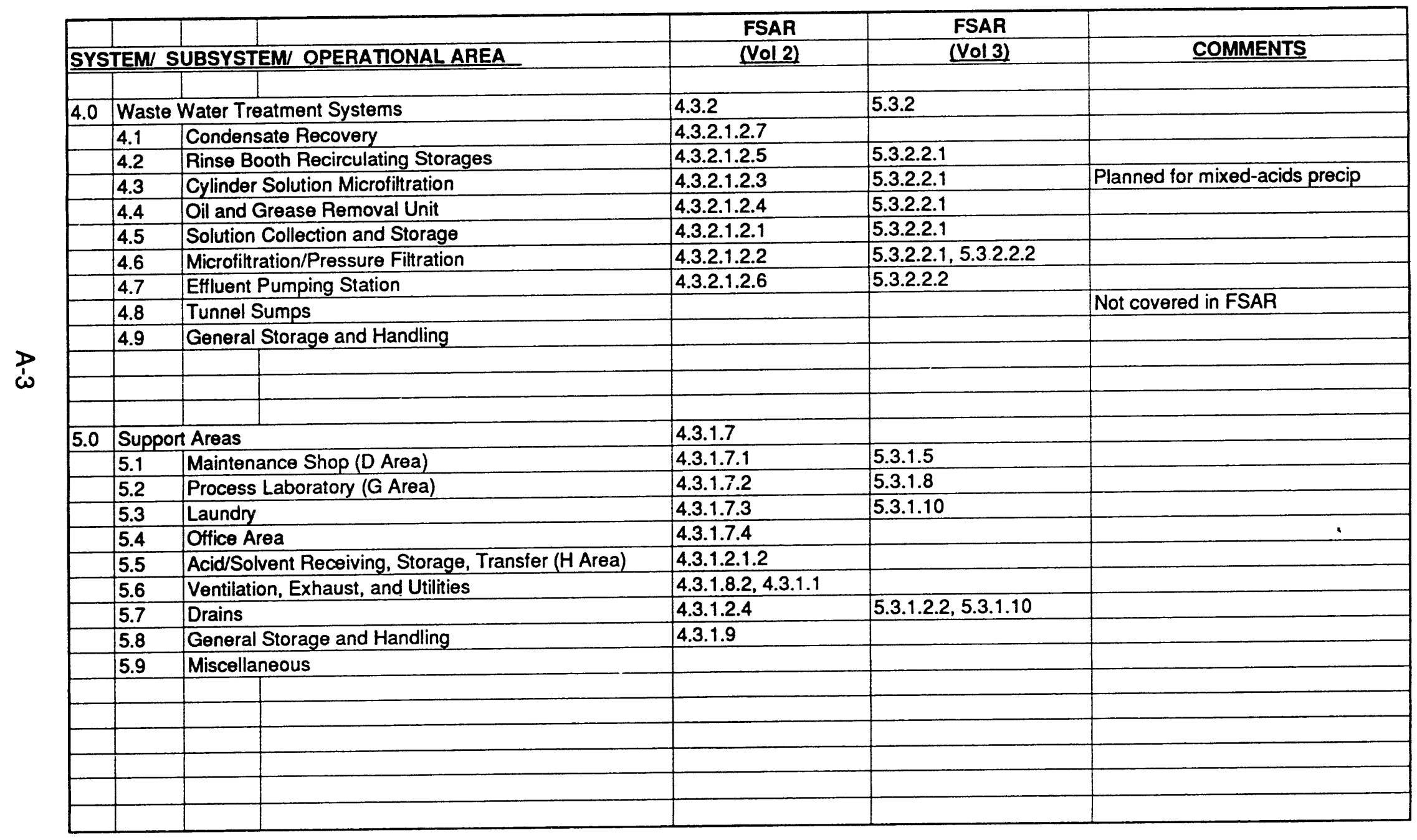




\section{APPENDIX B}

CORRELATION OF OSRS

WITH

SYSTEMS, SUBSYSTEMS, AND OPERATIONAL AREAS 







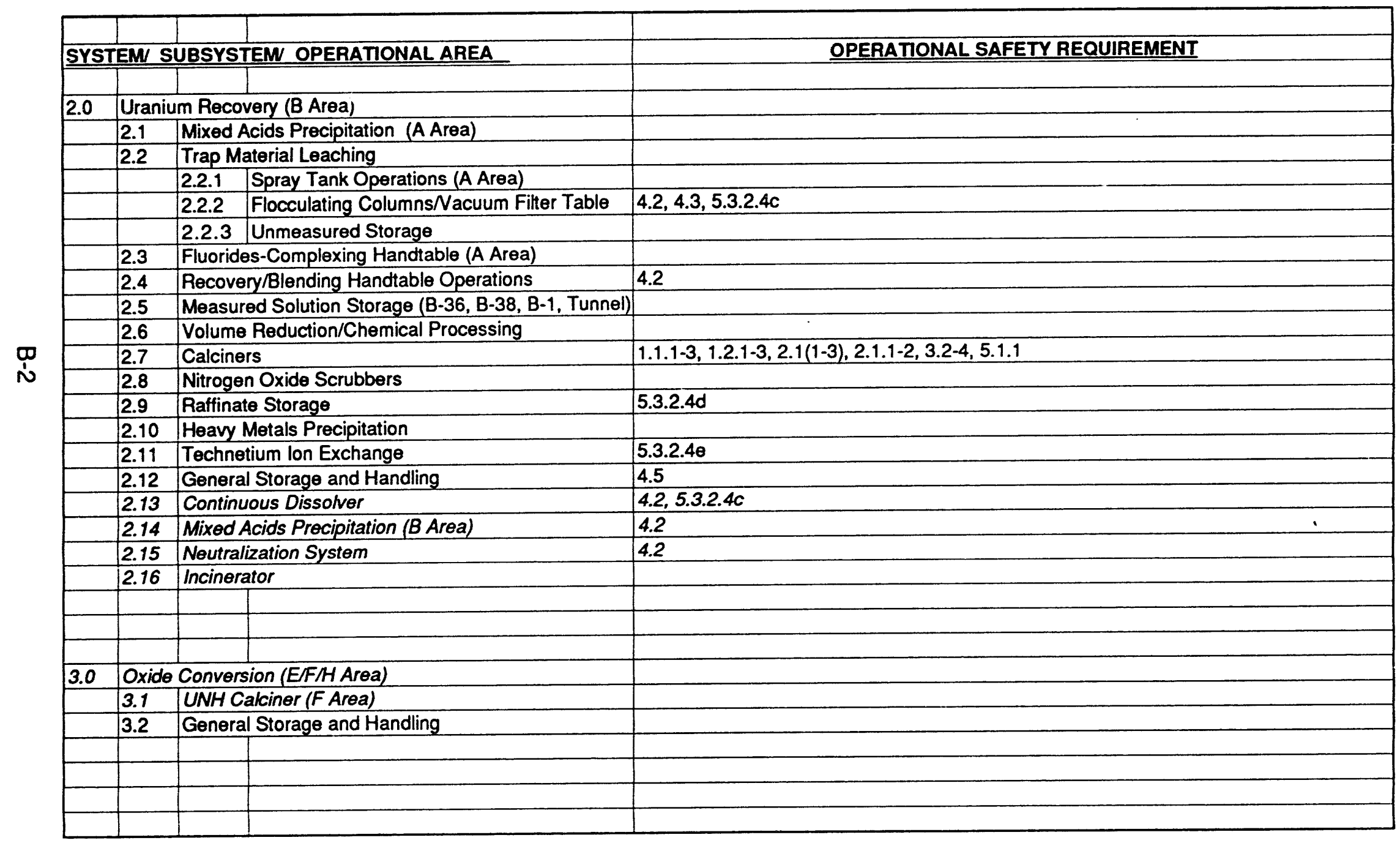




\begin{tabular}{|c|c|c|c|}
\hline \multicolumn{3}{|c|}{ SYSTEM SUBSYSTEM OPERATIONAL AREA } & OPERATIONAL SAFETY REQUIREMENT \\
\hline & & & \\
\hline \multirow{10}{*}{4.0} & \multicolumn{2}{|c|}{$\frac{1}{1}$ Waste Water Treatment Systems } & \\
\hline & 4.1 & Condensate Recovery & \\
\hline & 4.2 & Rinse Booth Recirculating Storages & $2.8,5.3 .2 .3(10)$ \\
\hline & 4.3 & Cylinder Solution Microfiltration & $2.10,5.3 .2 .3(7)$ \\
\hline & 4.4 & Oil and Grease Removal Unit & $2.3,2.10,5.3 .2 .3(6 b-c), 5.3 .2 .5(1 b)$ \\
\hline & 4.5 & Solution Collection and Storage & $5.3 .2 .3(5)$ \\
\hline & 4.6 & Microfiltration/Pressure Filtration & $1.1 .4-5,1.2 .4-5,2.1(5-6), 2.1 .4-5,2.5-6,2.10,3.2,3.4,5.3 .2 .3(8,9), 5.3 .2 .4 a, 5.3 .2 .5(2)$ \\
\hline & 4.7 & Effluent Pumping Station & 2.7 \\
\hline & 4.8 & Tunnel Sumps & \\
\hline & 4.9 & General Storage and Handling & 4.6 \\
\hline & & & \\
\hline & & & \\
\hline \multirow[t]{10}{*}{5.0} & \multicolumn{2}{|c|}{ Support Areas } & \\
\hline & 5.1 & Maintenance Shop (D Area) & \\
\hline & 5.2 & Process Laboratory (G Area) & \\
\hline & 5.3 & Laundry & \\
\hline & 5.4 & Office Area & \\
\hline & 5.5 & \multirow{2}{*}{$\begin{array}{l}\text { Acid/Solvent Receiving, Storage, Transfer (H Area) } \\
\text { Ventilation, Exhaust, and Utilities }\end{array}$} & \\
\hline & 5.6 & & 4.5 \\
\hline & 5.7 & Drains & \\
\hline & 5.8 & General Storage and Handling & $4.1,5.3 .2 .3(11)$ \\
\hline & 5.9 & Miscellaneous & $2.1(4), 2.1 .3,3.1,4.1,5.1 .1-2,5.2-7$ \\
\hline & & & \\
\hline & & & \\
\hline & & & \\
\hline & & & \\
\hline & & & \\
\hline
\end{tabular}


APPENDIX C

CORRELATION OF DMS, T-REPORTS, AND FCAS

WITH

SYSTEMS, SUBSYSTEMS, AND OPERATIONAL AREAS 


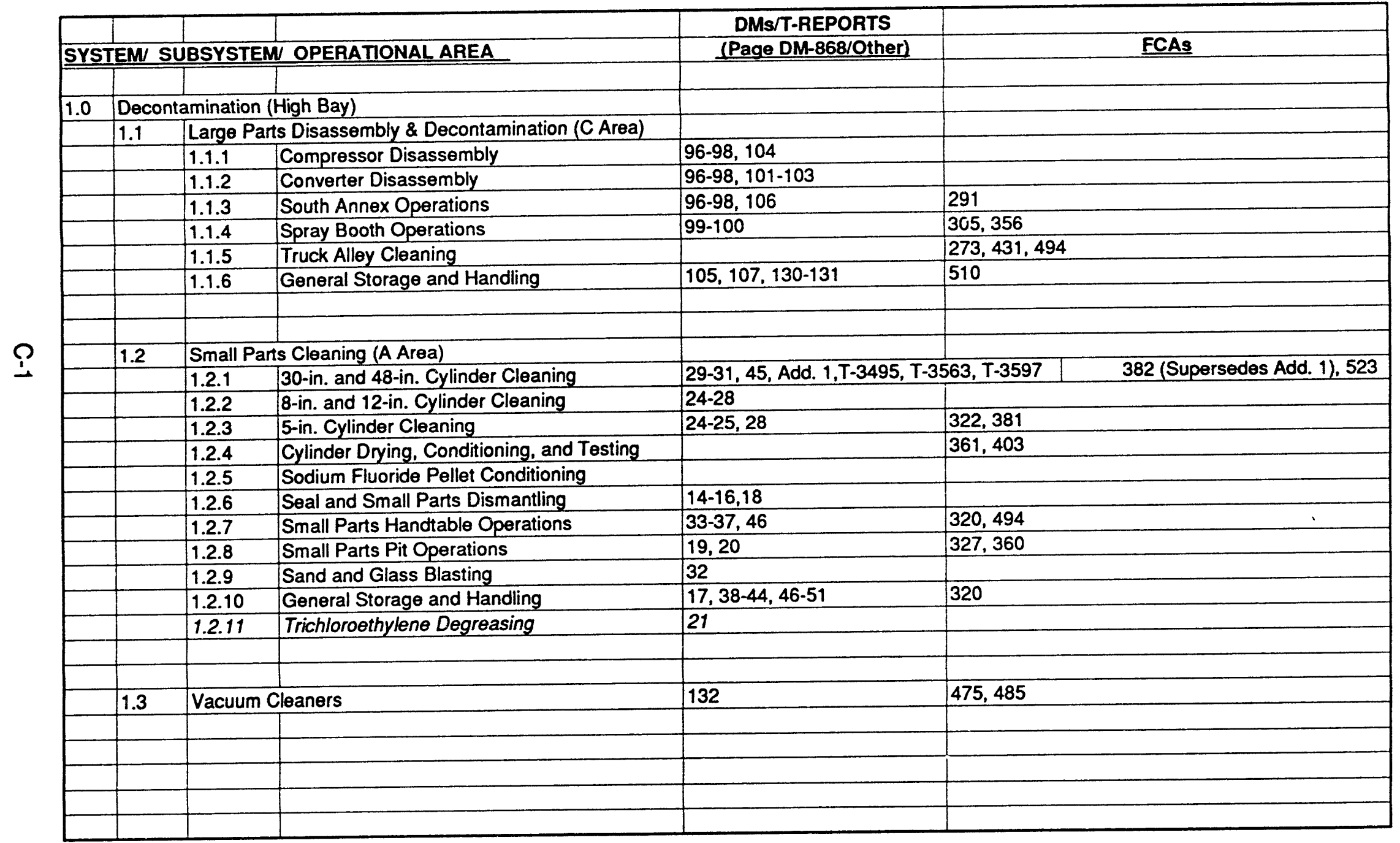









\begin{tabular}{|c|c|c|c|c|c|}
\hline & & & & DMs/T-REPORTS & \\
\hline \multicolumn{4}{|c|}{ SYSTEM/ SUBSYSTEM/ OPERATIONAL AREA } & (Page DM-868/Other) & FCAs \\
\hline & & & & & \\
\hline \multirow[t]{10}{*}{4.0} & \multicolumn{3}{|c|}{ Waste Water Treatment Systems } & & \\
\hline & 4.1 & \multicolumn{2}{|c|}{ Condensate Recovery } & & 358 \\
\hline & 4.2 & \multicolumn{2}{|c|}{ Rinse Booth Recirculating Storages } & & 356 \\
\hline & 4.3 & \multirow{2}{*}{\multicolumn{2}{|c|}{\begin{tabular}{|l|} 
Cylinder Solution Microfiltration \\
Oil and Grease Removal Unit
\end{tabular}}} & & 351 \\
\hline & 4.4 & Oil and Grease Removal Unit & & & 362,480 \\
\hline & 4.5 & \multicolumn{2}{|c|}{ Solution Collection and Storage } & & $327,355,359,360,361,363$ \\
\hline & 4.6 & \multicolumn{2}{|c|}{ Microfiltration/Pressure Filtration } & & $353,354,363$ \\
\hline & 4.7 & \multicolumn{2}{|c|}{ Effluent Pumping Station } & & 357 \\
\hline & 4.8 & \multicolumn{2}{|c|}{ Tunnel Sumps } & & 550 \\
\hline & 4.9 & \multicolumn{2}{|c|}{ General Storage and Handling } & & \\
\hline & & & & & \\
\hline & & & & & \\
\hline \multirow[t]{10}{*}{5.0} & Supp & Aroas & & & \\
\hline & 5.1 & \multicolumn{2}{|c|}{ Maintenance Shop (D Area) } & & \\
\hline & 5.2 & \multicolumn{2}{|c|}{ Process Laboratory (G Area) } & $122-127$ & $387,407,519,520,521$ \\
\hline & 5.3 & \multirow{2}{*}{\multicolumn{2}{|c|}{\begin{tabular}{|l|} 
Laundry \\
Office Area \\
\end{tabular}}} & & \\
\hline & 5.4 & & & & $\therefore$ \\
\hline & 5.5 & \multicolumn{2}{|c|}{ Acid/Solvent Receiving, Storage, Transfer (H Area) } & & \\
\hline & 5.6 & \multirow{2}{*}{\multicolumn{2}{|c|}{\begin{tabular}{|l|} 
Ventilation, Exhaust, and Utilities \\
Drains
\end{tabular}}} & $65,93-95$ & \\
\hline & 5.7 & & & & 480 \\
\hline & 5.8 & \multicolumn{2}{|c|}{ General Storage and Handling } & $8-11,13,38-43,130-135$ & $247,257,267,378,379,419,442,443,444,476$ \\
\hline & 5.9 & \multicolumn{2}{|c|}{ Miscellaneous } & $12,136-141$ & 305 \\
\hline & & & & & \\
\hline & & & & & \\
\hline & & & & & \\
\hline & & & & & \\
\hline & & & & & \\
\hline
\end{tabular}


APPENDIX D

NUMERICAL LISTING OF FCAS

FOR $\quad$ X-705

(PUBLISHED SINCE 1985) 


\begin{tabular}{|c|c|c|c|c|}
\hline$\overline{F C A}$ & DATE & PROBLEM [TITLE] & CANCELED BY & COMMENTS \\
\hline 247 & $1 / 30 / 85$ & Batching Uranium Concentrated Solutions. & & \\
\hline 250 & $3 / 7 / 85$ & Use of Large Containers in Heavy Metal Precipitation Area & & \\
\hline 257 & $5 / 7185$ & Transport of $5^{\circ}$ UF6 Clyinders and Oxide Containers in Secured Truck & & \\
\hline 264 & $11 / 6 / 85$ & Storage of Raffinate Calcination Process Solids in 55-gallon drums & & \\
\hline 267 & $11 / 18 / 85$ & Transport of Contaminated Burnables Drums trom $\times-326$ to $\times-705$ Radicator & & \\
\hline 272 & $3 / 21 / 86$ & Filter Table for $x-705$ Dissolver System & & \\
\hline 273 & $3 / 31 / 86$ & Use of $4^{\circ} \times 45^{\prime}$ Diameter Vat for $X-326$ Motor Cleaning & & \\
\hline 291 & $3 / 2 / 87$ & Installajion of 5 Diameter Can Holders Near West Wall of X-705 Annex & & \\
\hline 294 & $3 / 17 / 87$ & Storage of Contaminated Burnables and Contaminated Scrap Metal... & FCA-324 (2/15/88) & \\
\hline 305 & $8 / 7 / 87$ & Posting of NCS Administrative Controls and Limits X-705 & & \\
\hline 312 & $9 / 30 / 87$ & Construction of a Caged Storage Area for Gp $11 . .$. & FCA-320 $(2 / 15 / 88)$ & \\
\hline 320 & $2 / 15 / 88$ & A Caged Storage Area and Decomtamination Area for Gp III Materials in the Hi-Bay Area. X-705 & & \\
\hline 321 & $2 / 15 / 88$ & Caged Storage Area on the Mezzanine, X-705 & & \\
\hline 322 & $2 / 15 / 88$ & Cage Around the Small Cylinder Decontamination Unit and Storage Areas Within this Cage & & \\
\hline 324 & $2 / 15 / 88$ & Sorting Contaminated Waste ... on the Storage Pad Outside X-705 & FCA-434 $(5 / 24 / 90)$ & \\
\hline 327 & $4 / 19 / 88$ & Replacement of Pump P-103, X-705 & & \\
\hline 350 & $10 / 17 / 88$ & Iruck Alley, Truck Alley Pit.: & FCA-362 (1/6/89) & \\
\hline 351 & $10 / 17 / 88$ & Small and Large Cylinder Rinse Solutions (X-705 Environmental Projects) $X-705$ & & \\
\hline 352 & $10 / 17 / 88$ & PH Adjustment ( $X-705$ Environmental Projects), $X-705$ & FCA-363 (1/5/89) & \\
\hline 353 & $10 / 17 / 88$ & Operation of Filter Presses \#FP-1A and FP-1B (X-705 Emvironmental Projects), X-705 & & \\
\hline 354 & $10 / 18 / 88$ & Operation of the Effluent Microfiltration System (X-705 Environmental Projects), X-705 & & \\
\hline 355 & $10 / 18 / 88$ & Geometrically Sate 7000-Gallon Storage System (X-705 Environmental Projects). X-705 & & \\
\hline 356 & $10 / 18 / 88$ & Tunnel Rinse Booth Solutions (X-705 Environmental Projects) $X-705$ & & \\
\hline 357 & $10 / 18 / 88$ & Operation of the Effluent Pumping Station (X-705 Environmental Projects). $X-705$ & & \\
\hline 358 & $10 / 18 / 88$ & Recovery Evaporator Process Condensate (X-705 Environmental Projects) $X-705$ & & \\
\hline 359 & $10 / 18 / 88$ & Recovery NOX Scrubber Solutions (X-705 Environmental Projects) X-705 & & \\
\hline 360 & $10 / 18 / 88$ & Steam Pit Solutions (X-705 Environmental Projects), X-705 & & \\
\hline 361 & $10 / 18 / 88$ & Cylinder Hydrotest Solutions (X-705 Environmental Projects), X-705 & & \\
\hline
\end{tabular}




\begin{tabular}{|c|c|c|c|c|}
\hline FCA & DATE & PROBLEM [TITLE] & CANCELED BY & COMMENTS \\
\hline 362 & $1 / 6 / 89$ & Oill.Grease Removal System Operation, X-705 & & \\
\hline 363 & $1 / 5 / 89$ & pH Adjustment Systems, X-705 & & \\
\hline 366 & $4 / 6 / 89$ & Handtable for Cleaning Greasy Parts, X-705 & FCA-494 (3/20/91) & \\
\hline 373 & $6 / 9 / 89$ & Use of Handtable in Recovery Area. $X-705$ & & \\
\hline 374 & $6 / 16 / 89$ & Fivo-Inch Diameter Container Storage Area, Process Lab, X-705 & FCA-392 (11/29/89) & \\
\hline 377 & $7 / 6 / 89$ & 5-Inch Diameter Container Storage Area, X-705 & POEF-532 Letter & Storage area removed \\
\hline 378 & $716 / 89$ & 5-Inch Diameter Container Storage Area, $\times-705$ & & \\
\hline 379 & $7 / 7 / 89$ & 5-Inch Diameter Container Storage Area, X-705 & & \\
\hline 381 & $7 / 24 / 89$ & Modification to Small Cylinder Rinse Area, $X-705$ & & \\
\hline 382 & $8 / 22 / 89$ & Decontaminating $2.5-10$, and $14-$-Ton Cylinders, $X-705$ & & \\
\hline 383 & $8 / 25 / 89$ & Handtable for Cleaning Greasy Parts, X-705 & FCA-494 (3/20/91) & \\
\hline 387 & $9 / 18 / 89$ & Laboratory Waste Solution Holder $X-705$ & & \\
\hline 388 & $10 / 20 / 89$ & Small Rack in Recovery Area, X-705 & & \\
\hline 352 & $11 / 29 / 89$ & Five-Inch Diameter and Sample Container Storage Areas. Process Laboratory X-705 & FCA-407 (2/9/90) & \\
\hline 403 & $2 / 5 / 90$ & Posting NCS Administrative Controls and Limits & & \\
\hline 405 & 217190 & Recovery of North-South Safe Boundary Lines, X-705 & & \\
\hline 406 & $2 / 7190$ & Parking Spaces for Polybottle Carts in Recovery Area, X-705 & & \\
\hline 407 & $2 / 9 / 90$ & Five-Inch Diameter and Sample Container Storage Areas, Process Laboratory X-705 & & \\
\hline 419 & $4 / 9 / 90$ & Posting of NCS-related Administrative Controls and Limits & & \\
\hline 431 & $5 / 16 / 90$ & Cleaning Area 1 Seal Exhaust Oil Separators in X-705 & & \\
\hline 442 & $6 / 19 / 90$ & Posting of Administrative Controls and Limits & & \\
\hline 443 & $6 / 19 / 90$ & Posting of Administrative Controls and Limits & & \\
\hline 444 & $6 / 19 / 90$ & Posting of Administrative Controls and Limits & & \\
\hline 448 & $6 / 26 / 90$ & Sample Storage in X-705 Laboratory & FCA-519 (8/6/91) & \\
\hline 460 & $10 / 19 / 90$ & Posting of NCS Administrative Controls and Limits & & \\
\hline 475 & $12 / 13 / 90$ & Use of Vacuum Cleaners. & & \\
\hline 476 & $12 / 17 / 90$ & Sorting Contaminated Waste in X-705 & & \\
\hline 480 & $1 / 2 / 91$ & Relocation of Drains in the North Truck Alley, X-705 & & \\
\hline
\end{tabular}




\begin{tabular}{|c|c|c|c|c|}
\hline FCA & DATE & PROBLEM [TITLE] & CANCELED BY & COMMENTS \\
\hline 485 & $1 / 30 / 91$ & Use of Modified "Nuclear Safe" Vaguum Cleaners & & \\
\hline 494 & 3/20/91 & Use of Movable Handtables X. .705 & & \\
\hline 510 & $6 / 13 / 91$ & Sample Rack in High Bay Area X-705 & & \\
\hline 519 & $8 / 6 / 91$ & Sample Storage in Procoss Laboratory. X-705 & & \\
\hline 520 & $8 / 6 / 91$ & Removal of 5-Inch Diameter Storage Position X-705 & & \\
\hline 521 & $8 / 6 / 91$ & Contaminated Burnable Barrel in X-705 Process Laboratory & & \\
\hline 523 & $8 / 8 / 91$ & Withdrawal of Greater Than $4.5 \%$ U-235 Material into $48 \times 10-T o n$ Cylinders & & Affects cylinder deaning \\
\hline 533 & $12 / 11 / 91$ & Treatment of Cortaminated Ground Water in $X-700$ and $X-705$ Sumps & FCA-550 (4/8/92) & \\
\hline 546 & $3 / 20 / 92$ & Treatment of Contaminated Ground Water in $\times-700$ and $\times-705$ Sumps & FCA-550 (4/8/92) & \\
\hline 550 & $4 / 8 / 92$ & Troatment of Contaminated Ground Water in $\times-700$ and $\times-705$ Sumps & & \\
\hline 564 & $6 / 5 / 92$ & Evaporator Expansion Joints & FA $92-16(6 / 29 / 92)$ & \\
\hline & & & & \\
\hline
\end{tabular}




\section{APPENDIX E}

CORRELATION OF OMS and IPS WITH

SYSTEMS, SUBSYSTEMS, AND OPERATIONAL AREAS 


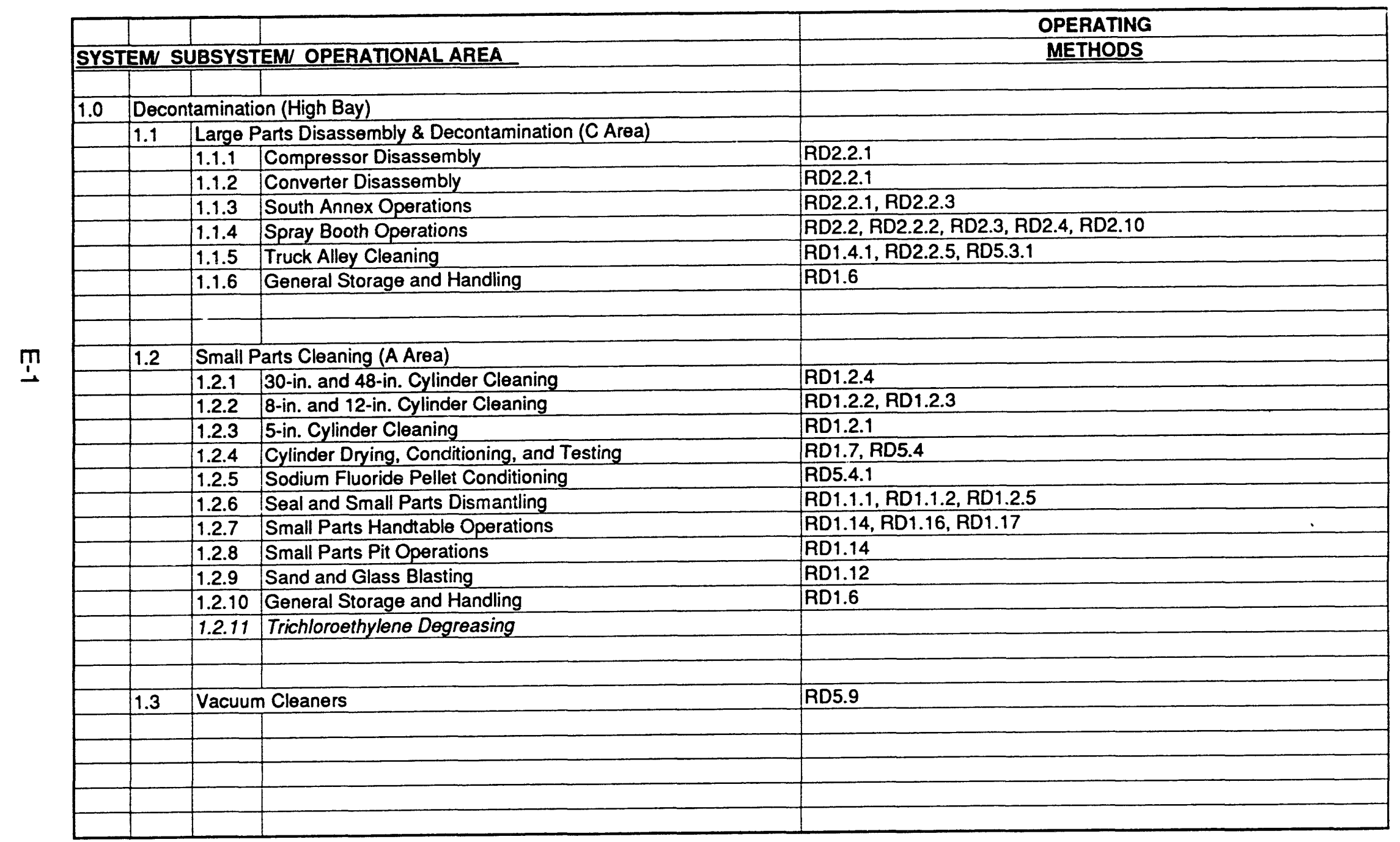




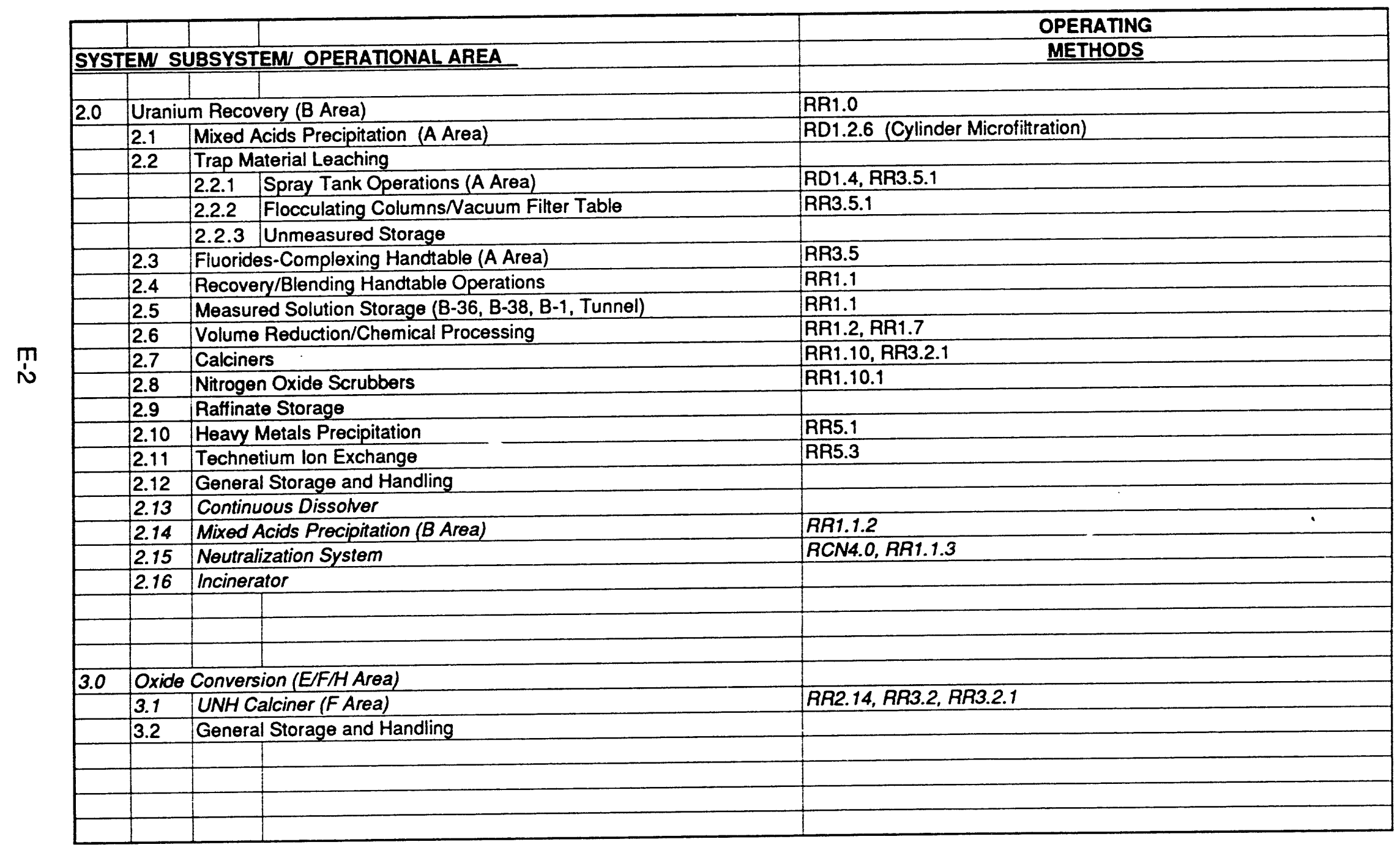




\begin{tabular}{|c|c|c|c|}
\hline & & & OPERATING \\
\hline \multicolumn{3}{|c|}{ SYSTEM SUBSYSTEM/ OPERATIONAL AREA } & METHODS \\
\hline & & & \\
\hline 4.0 & \multicolumn{2}{|c|}{ Waste Water Treatment Systems } & \\
\hline & 4.1 & Condensate Recovery & \\
\hline & 4.2 & Rinse Booth Recirculating Storages & RD2.4 \\
\hline & 4.3 & Cylinder Solution Microfiltration & RD1.2.6 \\
\hline & 4.4 & Oil and Grease Removal Unit & RD2.2.5 \\
\hline & 4.5 & Solution Collection and Storage & \\
\hline & 4.6 & Microfittration/Pressure Filtration & RR5.4, RR5.4.1 \\
\hline & 4.7 & Effluent Pumping Station & \\
\hline & 4.8 & Tunnel Sumps & RD2.9 \\
\hline & 4.9 & General Storage and Handling & \\
\hline & & & \\
\hline & & & \\
\hline \multirow[t]{10}{*}{5.0} & \multicolumn{2}{|c|}{ Support Areas } & \\
\hline & 5.1 & Maintenance Shop (D Area) & \\
\hline & 5.2 & Process Laboratory (G Area) & RD5.3 \\
\hline & 5.3 & Laundry & All RS \\
\hline & 5.4 & Office Area & \\
\hline & 5.5 & Acid/Solvent Receiving, Storage, Transfer (H Area) & RD4.1 \\
\hline & 5.6 & Ventilation, Exhaust, and Utilities & RA15.1, RA18.1, RCS2.3 \\
\hline & 5.7 & Drains & \\
\hline & 5.8 & General Storage and Handling & Various OMs of little concern to criticality \\
\hline & 5.9 & Miscellaneous & Various OMs of little concern to criticality \\
\hline & & & \\
\hline & & & \\
\hline & & & \\
\hline & & & \\
\hline & & & \\
\hline
\end{tabular}



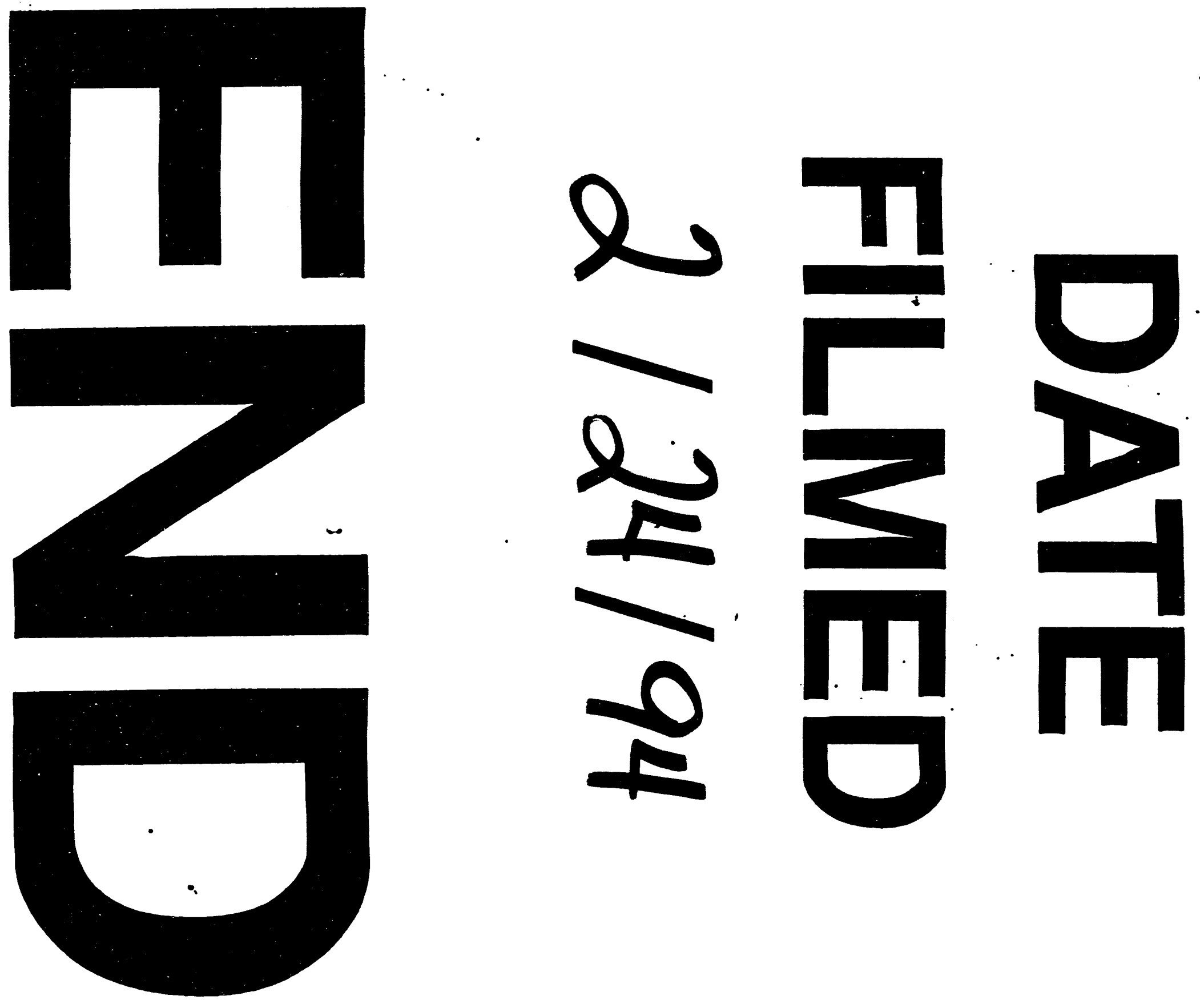
